\title{
Gender and Relationship Differences in Condom Use Among 15-24-Year-0lds in Angola
}

\begin{abstract}
By Ndola Prata, Farnaz Vahidnia and Ashley Fraser
\end{abstract}

Ndola Prata was the project coordinator for the Bay Area International Group at the University of California, Berkeley, during the data collection and analysis for this arti-

cle. She is currently specialist and lecturer, and Farnaz Vahidnia is associate specialist, in the Bixby Program in Population, Family Planning and Maternal Health, University of California,Berkeley,

CA, USA. Ashley

Fraser was staff research associate for the Bay Area International Group during the data analysis for this article.

CONTEXT: The sexual behavior of young people in Angola will play a major role in the future spread of HIV, yet few young people use condoms consistently, and reported rates of condom use are low. It is important to identify determinants of condom use among Angolan adolescents and young adults.

METHODS: Data for analysis came from 1,995 sexually experienced youth aged 15-24 who participated in a 2001 knowledge, attitudes and practices survey in Luanda, Angola. Logistic regression analysis was performed to identify predictors of consistent condom use by gender and determinants of condom use at last intercourse by type of relationship.

RESULTS: For both males and females, consistent condom use was positively associated with higher levels of education (odds ratios, 1.7-2.6) and believing that condoms did not diminish sexual pleasure (1.8 for both genders). It was negatively associated with being married or in a cohabiting relationship (0.1-0.5). Females who equated condom use with lack of trust were less likely to use condoms consistently (0.5), and males who believed that condoms were safe and those who had multiple partners were more likely to be consistent users (1.6 and 1.7, respectively). Urban residence, higher education, being in school and not equating condom use with lack of trust were important predictors of use at last intercourse in regular and casual relationships, whereas access to condoms was the most important factor in spousal relationships (4.5).

CONCLUSIONS: Intervention programs aimed at less educated, periurban and unemployed young people should be part of an effective HIV-prevention strategy. Such programs must address misperceptions among youth about condom use and the need for protection from HIV and other STIs.

International Family Planning Perspectives, 2005, 31(4):192-199

Condoms offer dual protection against unwanted pregnancy and some STIs, and are one of the most effective means of preventing the transmission of HIV. ${ }^{1}$ STIs have been shown to facilitate HIV infection, ${ }^{2}$ and therefore interventions to promote condom use are essential in efforts to slow the spread of HIV. To protect young people against infection, it is important to understand adolescent sexual behavior and the factors that influence their use of condoms.

In Sub-Saharan Africa, as in much of the rest of the world, a high proportion of people become sexually active during adolescence. ${ }^{3}$ Angola is no exception: The mean age of sexual debut among 14-20-year-olds is 14.4 for boys and 15.9 for girls, according to 1997 estimates. ${ }^{4}$ The sexual behavior of adolescents and youth will play a major role in the trajectory of the AIDS epidemic, for young people make up a large and growing proportion of the population in developing countries, ${ }^{5}$ and sexual habits formed during adolescence often persist into adulthood. ${ }^{6}$

Research suggests that adolescents are particularly vulnerable to contracting HIV. ${ }^{7}$ Most new HIV infections in SubSaharan African countries occur among youth aged 15-24, with prevalence in this age-group exceeding $20 \%$ in several nations. ${ }^{8}$ Adolescents may require guidance to temper their tendencies toward risk-taking and experimentation, and a lack of guidance leaves many unprepared to make the transition from childhood to adulthood. ${ }^{9}$ However, guid- ance, when offered, may be undermined by double standards, mixed messages and prohibitively rigid restrictions. ${ }^{10}$ Furthermore, though adolescents may be physiologically developed, they often are not emotionally mature. Their inexperience and impressionability, combined with their low social status and limited economic resources, make them vulnerable to exploitation. ${ }^{11}$

Yet young people may also be more open to innovation than older people; with effective promotion of safer sexual behaviors, adolescents may be more easily persuaded to change their behavior and adopt condom use. ${ }^{12}$ This opportunity for disease prevention points to a need for research on the sexual risk and protective behaviors of adolescents.

\section{BACKGROUND \\ Adolescents and Condom Use}

A review of the literature on adolescent sexual behavior reveals that condom use is influenced by social and demographic characteristics, knowledge about reproductive health, self-efficacy and attitudes regarding condoms, and issues of access and affordability. Behavior patterns appear to differ according to gender, age and education level, between students and nonstudents, and among nonstudents depending on their employment status. ${ }^{13}$ Residence and socioeconomic status also appear to influence sexual behavior, as do relationship type and marital status. ${ }^{14}$ 
Survey results from Sub-Saharan Africa indicate that young people possess some basic information about STIs, HIV/AIDS and pregnancy prevention, yet overall they receive much inaccurate information from rumors and myths. ${ }^{15}$ Furthermore, one study found that a considerable proportion of youth have little belief in their ability to successfully use condoms to protect themselves from HIV. ${ }^{16}$ They express concerns that requesting condom use communicates distrust, believe that contracting STIs is inevitable and worry that condoms might break and cause injury. ${ }^{17}$

Barriers to obtaining reproductive health information and services, such as inconvenient locations and operating hours, can be much more difficult for adolescents to overcome than for adults. Other barriers include regulations that prohibit or restrict provision of services and supplies on the basis of age or marital status, provider bias or disapproval of adolescent sexual activity, and lack of confidentiality. ${ }^{18}$ For these and other reasons, condom use among young people is quite low in most Sub-Saharan countries; for example, among unmarried women aged 15-19, only 4\% use condoms in South Africa, and fewer than 15\% use condoms in Tanzania, Malawi and Ethiopia. ${ }^{19}$ No previous studies have examined adolescent and young adult sexual behavior in Angola, nor are there estimates of condom use.

\section{Angola}

Since obtaining its independence from the Portuguese in 1975, Angola has been engulfed for almost three decades in a devastating civil war between the government of the Movimento Popular de Libertação de Angola (MPLA) party and the opposition União Nacional para a Independência Total de Angola (UNITA). The war has reduced a country rich in natural resources (e.g., oil and mineral deposits, notably diamonds) to one that is dependent on foreign aid for food, basic health care and social services for an estimated three million displaced people. The war was temporarily interrupted by three major cease-fires, most recently in 2002. This "final" cease-fire offers hope for long-term stability, but the government must now attempt to rebuild the nation, and there is a critical need to improve access to basic reproductive health services. ${ }^{20}$

The conflict restricted the movement of people, limiting both internal travel and traffic with neighboring countries. Though catastrophic from most perspectives, the protracted civil war may have insulated Angola from the explosion in HIV prevalence seen in more peaceful neighboring countries. ${ }^{21}$ Thus, peace may now increase Angola's vulnerability to the AIDS epidemic. Many displaced Angolans will eventually return to their homes, and an estimated 450,000 refugees will be repatriated. Free movement within Angola and across its borders will likely increase the spread of HIV. On the other hand, the civil war also limited the effectiveness of the government's HIV awareness campaigns.

On the basis of the limited information available, Angola's HIV prevalence is estimated at $6 \%$, having doubled between 1999 and 2001. ${ }^{22}$ Without effective governmental intervention, Angola may experience a sharp rise in the
TABLE 1. Percentage distribution of sexually experienced males and females aged 15-24, by social and demographic characteristics, according to gender and relationship, Knowledge, Attitudes and Practices Survey, Luanda, Angola, 2001

\begin{tabular}{|c|c|c|c|c|c|}
\hline \multirow[t]{2}{*}{ Characteristic } & \multicolumn{2}{|l|}{ Gender } & \multicolumn{3}{|c|}{ Relationship $†$} \\
\hline & $\begin{array}{l}\text { Male } \\
(\mathrm{N}=1,139)\end{array}$ & $\begin{array}{l}\text { Female } \\
(\mathrm{N}=856)\end{array}$ & $\begin{array}{l}\text { Spousal } \\
(\mathrm{N}=263)\end{array}$ & $\begin{array}{l}\text { Regular } \\
(\mathrm{N}=855)\end{array}$ & $\begin{array}{l}\text { Casual } \\
(\mathrm{N}=737)\end{array}$ \\
\hline \multicolumn{6}{|l|}{ Age } \\
\hline $15-19$ & 58.3 & 58.8 & 24.7 & 56.5 & 62.8 \\
\hline $20-24$ & 41.7 & 41.2 & 75.3 & 43.5 & 37.2 \\
\hline \multicolumn{6}{|l|}{ Residence } \\
\hline Urban & 27.6 & 27.8 & 20.1 & 30.6 & 25.8 \\
\hline Periurban & 72.4 & 72.2 & 79.9 & 69.4 & 74.2 \\
\hline \multicolumn{6}{|l|}{ Yrs. of education } \\
\hline$\leq 5$ & 13.5 & $22.8^{*}$ & 24.0 & $14.3^{*}$ & $14.5^{*}$ \\
\hline $6-7$ & 30.2 & $27.2^{*}$ & 31.9 & $24.7^{*}$ & 30.9 \\
\hline $8-9$ & 40.2 & $34.5^{*}$ & 30.8 & 43.1 & 37.0 \\
\hline$\geq 10$ & 16.1 & 15.5 & 13.3 & 17.9 & 17.5 \\
\hline \multicolumn{6}{|l|}{ Marital status } \\
\hline Single & 90.1 & $82.5^{*}$ & na & 94.3 & 95.8 \\
\hline Married or cohabiting & 9.9 & 17.5 & 100.0 & 5.7 & 4.2 \\
\hline \multicolumn{6}{|l|}{ Employment } \\
\hline Student & 60.2 & 56.7 & 14.1 & $59.9^{*}$ & $59.8^{*}$ \\
\hline Employed & 30.3 & $20.0^{*}$ & 52.9 & $27.6^{*}$ & $27.1^{*}$ \\
\hline Unemployed & 9.5 & $23.4^{*}$ & 33.0 & $12.5^{*}$ & $13.0^{*}$ \\
\hline Total & 100.0 & 100.0 & 100.0 & 100.0 & 100.0 \\
\hline
\end{tabular}

prevalence of HIV. ${ }^{23}$ The sexual behavior of adolescents and young adults, especially their condom use, will play a crucial role in affecting the course of the epidemic. ${ }^{24}$ Because the level of sexual activity and the incidence of STIs are high among 15-24-year-olds, ${ }^{25}$ these factors may contribute to the rapid spread of HIV.

Little information is available to guide policymakers' decisions or help program managers design interventions to address the health needs of young people in Angola. Given the limited resources available and the immediacy of the threat, it is essential that prevention programs be developed and quickly implemented across the nation.

The purpose of this study was to identify determinants of condom use among adolescents and young adults in Angola. We analyzed data from a recent survey to examine consistent condom use for each gender, as well as condom use at last sexual intercourse for partners in spousal, regular and casual relationships.

\section{METHODS}

The data used in this study are from a knowledge, attitudes and practices (KAP) survey conducted in January 2001 by the Angolan Institute for Research as part of a condom social marketing program directed by Population Services International. The survey included 2,419 males and females aged 15-24 who lived in Luanda, the capital of Angola. It used a stratified random sample that included all nine municipalities of Luanda province, each representing a stratum. The number of households selected for interviewing in each stratum was proportional to its population size. In 
households with more than one target member, a respondent was randomly selected. The sample was representative of this age-group in Luanda.

For this study, we used data collected from 1,995 sexually experienced respondents. We analyzed social and demographic characteristics, sexual debut, number of partners in the past three months, knowledge of condoms and risk of STIs and HIV, attitudes toward condoms and selfefficacy, and access to and affordability of condoms. We disaggregated the data according to gender and relationship type (spousal, regular and casual). Spousal relationships included those of married or cohabiting couples; regular and casual relationships referred to those occurring with a "regular" or "casual" partner in the 12 months preceding the survey. Questions about casual and regular relationships referred to the most recent such partner with whom the respondent had had sexual intercourse (e.g., for married or cohabiting individuals, "Other than your spouse, do you have a regular and/or casual sex partner?"; for unmarried individuals, "Do you have a regular and/or casual sex partner?"). Married or cohabiting respondents could also have a regular or casual partner, or both; likewise, unmarried respondents could have either or both types of partners.

The outcome variables of consistent condom use and condom use at last intercourse are both dichotomous (i.e., always use vs. not always, and use vs. nonuse, respectively). Consistent condom use was assigned to respondents who reported "always" using condoms with all reported partners in the three months before their interview. For regular and casual partners, we have information only on con-

\begin{tabular}{|c|c|c|c|c|c|}
\hline \multirow[t]{2}{*}{ Characteristic } & \multicolumn{2}{|c|}{ Gender } & \multicolumn{3}{|c|}{ Relationship } \\
\hline & Male & Female & Spousal & Regular & Casual \\
\hline \multicolumn{6}{|l|}{ \% DISTRIBUTIONS } \\
\hline \multicolumn{6}{|l|}{ No. of partners in last 3 mos. } \\
\hline 0 & 20.5 & 19.0 & 1.5 & 5.5 & 9.3 \\
\hline 1 & 45.3 & $74.4^{*}$ & 85.2 & 64.1 & 44.5 \\
\hline 2 & 17.6 & $3.0^{*}$ & 8.8 & 15.3 & 23.1 \\
\hline$\geq 3$ & 16.6 & $3.5^{*}$ & 4.5 & 15.1 & 23.1 \\
\hline \multicolumn{6}{|l|}{ PERCENTAGES } \\
\hline \multicolumn{6}{|l|}{ Knowledge } \\
\hline Agrees condoms prevent pregnancy & 85.2 & $80.3^{*}$ & 76.1 & $86.4^{*}$ & $86.2^{*}$ \\
\hline Agrees condoms prevent STls & 89.0 & 88.2 & 86.7 & 88.0 & $91.6^{*}$ \\
\hline \multicolumn{6}{|l|}{ Agrees correct use of condoms } \\
\hline every time reduces risk of HIV & 86.3 & $81.0^{*}$ & 84.8 & 83.5 & 85.2 \\
\hline Believes condoms break easily & 33.3 & 29.4 & 29.3 & 33.8 & 34.5 \\
\hline \multicolumn{6}{|l|}{ Attitudes and self-efficacy } \\
\hline Believes condoms are safe & 75.3 & 70.7 & 63.7 & 74.6 & 75.8 \\
\hline Equates condom use with lack of trust & 24.8 & 22.9 & 30.8 & 24.8 & 26.1 \\
\hline \multicolumn{6}{|l|}{ Believes condoms are difficult } \\
\hline to use with new partner & 32.0 & 37.4 & 34.2 & 34.4 & 35.7 \\
\hline Believes condoms diminish pleasure & 39.7 & 34.1 & 39.9 & 39.2 & 43.0 \\
\hline Is embarrassed when buying condoms & 7.6 & $18.6^{*}$ & 17.1 & $11.0^{*}$ & $9.4^{*}$ \\
\hline \multicolumn{6}{|l|}{ Access and affordability } \\
\hline Thinks condoms are difficult to find & 16.2 & 15.5 & 10.3 & 17.0 & $18.1^{*}$ \\
\hline Thinks condoms are expensive & 14.9 & 10.6 & 6.8 & 13.8 & $14.1^{*}$ \\
\hline
\end{tabular}

dom use at last intercourse. The last intercourse with a specific partner could have happened any time during the 12 months preceding the survey.

We grouped independent variables as social and demographic characteristics; sexual behavior; general knowledge of condoms and STIs; self-efficacy and attitudes regarding condoms; and access and affordability. For the bivariate analyses, we used t tests to determine significant differences at $\mathrm{p}<.05$. We used logistic regression analysis to assess associations between consistent condom use and the various characteristics, by gender, as well as for associations between condom use at last intercourse and these characteristics, by type of relationship. We considered the contribution of the entire set of variables by adding one variable at a time to the regression.

\section{RESULTS}

\section{Sample Characteristics}

The sample included 1,995 sexually active respondents aged 15-24, of whom 1,139 were male and 856 female (Table 1, page 193). The majority were 19 or younger and lived in periurban neighborhoods. Overall, males had more education than females. Most respondents (90\% of males and $83 \%$ of females) were single at the time of the survey. Males and females were equally likely to be students, but males reported a higher rate of employment (30\% vs. 20\%).

On average, respondents in regular and casual relationships were younger than those in spousal relationships: About $60 \%$ of the former were aged 15-19, compared with $25 \%$ of those who were married or cohabiting. The proportion of respondents who had five or fewer years of education was significantly higher among those in spousal relationships than among those in other types of relationships (24\% vs. 14-15\%). The majority of young people involved in regular and casual relationships were single at the time of the survey (94-96\%); among married respondents, 4-6\% were involved in nonspousal relationships. There were significant differences in employment among the groups: Respondents in spousal relationships were less likely than those in regular or casual relationships to be students (14\% vs. $60 \%)$, and they were about twice as likely to be employed (53\% vs. $27-28 \%$ ).

\section{Behavior, Knowledge and Attitudes}

Males were significantly more likely than females to have had sex before age 15 (48\% vs. 24\% —not shown). About 20\% of both males and females reported having had no sexual partners in the three months preceding the survey (Table 2). Males were significantly less likely than females to report having had one partner (45\% vs. 74\%), and more likely to report two partners (18\% vs. $3 \%$ ) or three or more partners (17\% vs. $4 \%$ ) during that period. Eight percent of males acknowledged visiting commercial sex workers in the last 12 months (not shown).

Between about $70 \%$ and $90 \%$ of the respondents had accurate knowledge about condom use. Men were more knowledgeable than women about preventing pregnancy 
( $85 \%$ vs. $80 \%$ ) and HIV infection (86\% vs. $81 \%$ ). Although about three-quarters of respondents thought that condoms are safe, one-fourth equated condom use with lack of trust and one-third said they are difficult to use with new partners. Males were significantly less likely than females to feel embarrassed about buying condoms (8\% vs. 19\%).

Respondents in spousal relationships were significantly less knowledgeable than those in casual relationships about preventing pregnancy (76\% vs. $86 \%$ ) and STIs (87\% vs. $92 \%)$. Spousal partners were also less knowledgeable than regular partners regarding pregnancy prevention. Youth in spousal relationships were significantly more likely to be embarrassed about buying condoms than were those in either regular or casual relationships (17\% vs. 11\% and 9\%). A greater proportion of respondents in casual relationships than of those in spousal relationships expressed concern about condom access (18\% vs. 10\%) and affordability (14\% vs. $7 \%)$.

\section{Condom Use}

A significantly larger proportion of males than of females indicated that they had always used condoms with all of their partners in the three months preceding the survey (17\% vs. $12 \%$-Table 3$)$. Males in both age-groups were more likely than females to be consistent users (19\% vs. 13\% among the younger respondents, and 15\% vs. 9\% among the older youth), as were males residing in urban areas (25\% vs. 19\%) and periurban areas (14\% vs. 9\%). At each level of education except the highest, males were significantly more likely than females to report condom use. A larger proportion of single males than of single females were consistent users (19\% vs. 14\%), and males who were students or employed reported more condom use (22\% and $11 \%$, respectively) than their female counterparts (17\% and 4\%.)

As expected, condom use at last intercourse was significantly higher in casual (40-44\%) and regular relationships (38-39\%) than in spousal relationships (18-21\%). It was higher in regular and casual relationships than in spousal relationships for respondents who were urban or periurban residents, students or employed. Furthermore, use in casual and regular relationships was higher than in spousal relationships at all education levels. Across relationship types, such use was not associated with gender, age or marital status.

\section{Multivariate Analyses}

- Differences by gender. As Table 4 (page 196) shows, consistent condom use among males was positively associated with having 8-9 years of education (odds ratio, 1.7), having had two or more partners in the last three months (1.7), agreeing that condoms are safe (1.6) and disagreeing with the statement that condoms diminish pleasure (1.8). Married or cohabiting males had lower odds of being consistent users than did those who were single (0.5).

Females with 8-9 years and 10 or more years of education were more likely to be consistent users than those with five or fewer years of education (odds ratios, 2.0 and 2.6, respectively). Those who disagreed with the statement that
TABLE 3. Measures of condom use, by gender and by type of relationship, according to respondent characteristics

\begin{tabular}{|c|c|c|c|c|c|}
\hline \multirow[t]{2}{*}{ Characteristic } & \multicolumn{2}{|c|}{ Consistent use $†$} & \multicolumn{3}{|c|}{ Use at last intercourse $\neq$} \\
\hline & Male & Female & Spousal & Regular & Casual \\
\hline \multicolumn{6}{|l|}{ Gender } \\
\hline Male & 17.0 & na & 17.7 & $38.2^{*}$ & $43.5^{*}$ \\
\hline Female & na & $11.5^{*}$ & 21.3 & $39.3^{*}$ & $40.4^{*}$ \\
\hline \multicolumn{6}{|l|}{ Age } \\
\hline $15-19$ & 18.7 & $13.3^{*}$ & 22.7 & $40.7^{*}$ & $42.9 *$ \\
\hline $20-24$ & 14.7 & $8.8^{*}$ & 18.8 & $36.2^{*}$ & $42.7^{*}$ \\
\hline \multicolumn{6}{|l|}{ Residence } \\
\hline Urban & 25.2 & $18.5^{*}$ & 23.1 & $46.9^{*}$ & $54.7^{*}$ \\
\hline Periurban & 13.9 & $8.7^{*}$ & 19.0 & $35.1^{*}$ & $38.6^{*}$ \\
\hline \multicolumn{6}{|c|}{ Yrs. of education } \\
\hline$\leq 5$ & 6.6 & $3.1^{*}$ & 15.9 & $21.3^{*}$ & $23.4^{*}$ \\
\hline $6-7$ & 14.5 & $9.0^{*}$ & 20.5 & $38.0^{*}$ & $34.2^{*}$ \\
\hline $8-9$ & 19.7 & $13.5^{*}$ & 23.2 & $40.5^{*}$ & $49.8^{*}$ \\
\hline$\geq 10$ & 24.0 & 23.3 & 17.1 & $49.4^{*}$ & $59.2^{*}$ \\
\hline \multicolumn{6}{|l|}{ Marital status } \\
\hline Single & 18.6 & $13.5^{*}$ & na & 38.3 & 42.7 \\
\hline Married or & & & & & \\
\hline cohabiting & 2.7 & 0.7 & 20.0 & 43.2 & 44.8 \\
\hline \multicolumn{6}{|l|}{ Employment } \\
\hline Student & 22.3 & $16.7^{*}$ & 31.6 & $45.6^{*}$ & $48.3^{*}$ \\
\hline Employed & 11.0 & $4.1^{*}$ & 15.0 & $31.1^{*}$ & $35.7^{*}$ \\
\hline Unemployed & 7.8 & 5.0 & 22.4 & 23.2 & 32.3 \\
\hline
\end{tabular}

*Significantly different from males, or from spousal relationships, at $\mathrm{p}<.05$. tConsistent use defined as always using condoms with all reported partners in the last three months. 生e at last intercourse could have happened any time during the last 12 months. Note: na=not applicable.

condoms diminish pleasure also had an elevated likelihood of consistent use (1.8). Consistent use was less likely among females who were married or cohabiting (0.1), and among those who equated condom use with lack of trust (0.5).

The odds of consistent use among males and females differed significantly for only three variables. Males who lived in periurban areas, were married or cohabiting, or equated condom use with lack of trust were more likely than their female counterparts to be consistent users.

-Differences by relationship type. For young people in spousal relationships, only two variables were associated with condom use at last intercourse within the past 12 months: Equating condom use with lack of trust reduced the likelihood of use (odds ratio, 0.3), whereas perceived access to condoms increased the likelihood of use (4.5Table 5, page 197). For respondents in a relationship with a regular partner, the odds of condom use were reduced by living in a periurban area rather than an urban area (0.6) and equating condoms with lack of trust (0.5). However, the odds of condom use were increased among regular partners who had 10 or more years of education (2.0), were married or cohabiting (2.3) or agreed that condoms prevent pregnancy (2.4).

The odds of condom use at last intercourse were elevated among individuals in casual relationships who had 8-9 years or 10 or more years of education (odds ratios, 2.8 and 3.7, respectively), as well as among those who thought condoms were affordable (1.7). In contrast, the odds were re- 
TABLE 4. Odds ratios (and 95\% confidence intervals) from logistic regression analyses assessing associations between consistent condom use and selected characteristics, by gender

\begin{tabular}{|c|c|c|c|c|c|}
\hline Characteristic & Male & Female & Characteristic & Male & Female \\
\hline \multirow{2}{*}{\multicolumn{3}{|c|}{$\begin{array}{l}\text { SOCIAL AND DEMOGRAPHIC } \\
\text { Age }\end{array}$}} & \multirow{2}{*}{\multicolumn{3}{|c|}{$\begin{array}{l}\text { KNOWLEDGE (continued) } \\
\text { Condoms prevent STIs }\end{array}$}} \\
\hline & & & & & \\
\hline $15-19$ & 1.00 & 1.00 & Disagree & 1.00 & 1.00 \\
\hline $20-24$ & $1.20(0.89-1.61)$ & $0.87(0.60-1.27)$ & Agree & $0.54(0.35-0.84)$ & $0.65(0.39-1.07)$ \\
\hline \multicolumn{3}{|l|}{ Residence } & \multicolumn{3}{|c|}{ Correct and consistent condom use reduces risk of HIV } \\
\hline Urban & 1.00 & 1.00 & Disagree & 1.00 & 1.00 \\
\hline Periurbant & $1.32(0.99-1.77)$ & $0.75(0.53-1.07)$ & Agree & $1.33(0.90-1.96)$ & $1.04(0.68-1.57)$ \\
\hline \multicolumn{3}{|l|}{ Yrs. of education } & \multicolumn{3}{|l|}{ Condoms break easily } \\
\hline$\leq 5$ & 1.00 & 1.00 & Agree & 1.00 & 1.00 \\
\hline $6-7$ & $1.40(0.90-2.17)$ & $1.58(0.95-2.61)$ & Disagree & $1.09(0.82-1.45)$ & $1.23(0.85-1.78)$ \\
\hline $8-9$ & $1.74(1.13-2.69)^{*}$ & $2.02(1.23-3.31)^{* *}$ & & & \\
\hline$\geq 10$ & $1.54(0.92-2.59)$ & $2.59(1.42-4.71)^{* *}$ & \multicolumn{3}{|c|}{$\begin{array}{l}\text { ATTITUDES AND SELF-EFFICACY } \\
\text { Condoms are safe }\end{array}$} \\
\hline \multicolumn{3}{|l|}{ Marital status } & Disagree & 1.00 & 1.00 \\
\hline Single & 1.00 & 1.00 & Agree & $1.60(1.13-2.26)^{* *}$ & $1.42(0.95-2.14)$ \\
\hline Married or cohabiting $\dagger$ & $0.45(0.28-0.73)^{* *}$ & $0.12(0.06-0.25)^{* *}$ & \multicolumn{3}{|c|}{ Condom use equated with lack of trust } \\
\hline \multicolumn{3}{|l|}{ Employment } & Disagree & 1.00 & \\
\hline Student & 1.00 & 1.00 & \multirow[b]{2}{*}{ Condomsare difficult to uce } & \multirow[t]{2}{*}{$0.81(0.60-1.11)$} & \multirow[t]{2}{*}{$0.46(0.30-0.72)^{* *}$} \\
\hline \multirow{2}{*}{ Unemployed } & $\begin{array}{l}1.14(0.83-1.57) \\
1.21(0.77-1.89)\end{array}$ & $\begin{array}{l}1.53(0.97-2.42) \\
0.92(0.58-1.47)\end{array}$ & & & \\
\hline & & & $\begin{array}{l}\text { Condoms are difficult to use } \\
\text { Disagree }\end{array}$ & \multicolumn{2}{|c|}{ Condoms are difficult to use with new partner } \\
\hline SEXUAL BEHAVIOR & & & Agree & $0.88(0.67-1.17)$ & $0.86(0.61-1.20)$ \\
\hline \multicolumn{3}{|c|}{ Sexually active before age 15} & & & \\
\hline No & 1.00 & 1.00 & \multicolumn{3}{|c|}{ Condoms diminish pleasure } \\
\hline \multirow[b]{2}{*}{ No } & $1.17(0.90-1.51)$ & $0.95(0.65-1.41)$ & Agree & 1.00 & 1.00 \\
\hline & \multicolumn{2}{|c|}{ No. of partners in last 3 mos. } & Disagree & $1.84(1.42-2.40)^{* *}$ & $1.77(1.27-2.47)^{* *}$ \\
\hline 1 & 1.00 & 1.00 & \multirow{2}{*}{\multicolumn{3}{|c|}{ Embarrassed when buying condoms }} \\
\hline \multirow[t]{2}{*}{$\geq 2$} & $1.66(1.27-2.17)^{* *}$ & $1.14(0.63-2.08)$ & & & \\
\hline & & & Disagree & 1.00 & 1.00 \\
\hline \multicolumn{3}{|c|}{ Visited commercial sex worker in last 12 mos. } & Agree & $0.75(0.45-1.26)$ & $0.80(0.49-1.28)$ \\
\hline No & 1.00 & na & \\
\hline Yes & $1.55(0.95-2.51)$ & na & & \multicolumn{2}{|c|}{ Condoms are difficult to find } \\
\hline \multirow{2}{*}{\multicolumn{3}{|c|}{$\begin{array}{l}\text { KNOWLEDGE } \\
\text { Condoms prevent pregnancy }\end{array}$}} & Agree & 1.00 & 1.00 \\
\hline & & & Disagree & $1.16(0.83-1.63)$ & $1.48(0.97-2.27)$ \\
\hline Disagree & 1.00 & 1.00 & & & \\
\hline Agree & $0.97(0.66-1.43)$ & $1.40(0.89-2.20)$ & Condoms are affordable & & \\
\hline & & & $\begin{array}{l}\text { Disagree } \\
\text { Agree }\end{array}$ & $\begin{array}{l}1.00 \\
1.30(0.97-1.74)\end{array}$ & $\begin{array}{l}1.00 \\
1.24(0.87-1.77)\end{array}$ \\
\hline & & & -2 log likelihood & 1415.8 & 934.6 \\
\hline
\end{tabular}

duced among casual partners who were periurban residents (0.6), employed (0.6), embarrassed when buying condoms (0.5) or equated condoms with lack of trust (0.7).

\section{DISCUSSION}

The results of this study suggest that numerous factors are associated with our two measures of condom use, and that these associations vary by gender and type of relationship. Because the 2001 KAP survey was the first of its kind in Angola, this study offers some initial insights into the determinants of condom use among the country's youth. Previous surveys had found extremely low levels of use, ${ }^{26}$ but little other information on this subject has been available.

The research literature reveals differences in sexual behavior between young men and women, ${ }^{27}$ and an understanding of these differences is essential for developing effective programs that promote condoms, a male-controlled method. In our study, consistent condom use among males and females was associated with different sets of factors, but with some overlap: Having 8-9 years of education and disagreeing that condoms diminish pleasure were positive factors, and being married was a negative factor. However, only three variables differed significantly between males and females, and of these, only periurban residence yielded both positive and negative associations. We also detected important differences in condom use at last intercourse by type of relationship. To develop intervention programs in Angola, it is critical to understand how condom use varies among spousal, regular and casual relationships, and specific educational approaches may be needed to target youth engaged in a variety of sexual relationships.

Although condom use by married women in Angola is negligible ${ }^{28}$ and fewer than one-fifth of respondents in our study reported consistent use, it is noteworthy that about two-fifths of all youth in regular and casual relationships reported condom use at last intercourse. This level of use indicates a relatively high level of knowledge and desire to use condoms among adolescents and young adults in Lu- 


\begin{tabular}{|c|c|c|c|c|c|c|c|}
\hline $\begin{array}{l}\text { Charac- } \\
\text { teristic }\end{array}$ & $\begin{array}{l}\text { Spousal } \\
(\mathrm{N}=263)\end{array}$ & $\begin{array}{l}\text { Regular } \\
(\mathrm{N}=854)\end{array}$ & $\begin{array}{l}\text { Casual } \\
(\mathrm{N}=736)\end{array}$ & $\begin{array}{l}\text { Charac- } \\
\text { teristic }\end{array}$ & $\begin{array}{l}\text { Spousal } \\
(\mathrm{N}=263)\end{array}$ & $\begin{array}{l}\text { Regular } \\
(\mathrm{N}=854)\end{array}$ & $\begin{array}{l}\text { Casual } \\
(\mathrm{N}=736)\end{array}$ \\
\hline \multicolumn{4}{|c|}{$\begin{array}{l}\text { SOCIAL AND DEMOGRAPHIC } \\
\text { Age }\end{array}$} & \multicolumn{4}{|c|}{$\begin{array}{l}\text { KNOWLEDGE (continued) } \\
\text { Condoms prevent STIs }\end{array}$} \\
\hline $15-19$ & 1.00 & 1.00 & 1.00 & Disagree & 1.00 & 1.00 & 1.00 \\
\hline $20-24$ & $0.77(0.35-1.70)$ & $0.87(0.62-1.22)$ & $0.87(0.60-1.25)$ & Agree & $2.65(0.65-10.78)$ & $0.85(0.52-1.40)$ & $0.60(0.32-1.12)$ \\
\hline \multicolumn{4}{|l|}{ Gender } & \multicolumn{4}{|c|}{ Correct and consistent condom use reduces risk of HIV } \\
\hline Female & 1.00 & 1.00 & 1.00 & Disagree & 1.00 & 1.00 & 1.00 \\
\hline Male & $1.49(0.62-3.55)$ & $1.04(0.73-1.48)$ & $0.76(0.49-1.17)$ & Agree & $0.53(0.19-1.47)$ & $1.10(0.72-1.68)$ & $1.33(0.83-2.13)$ \\
\hline \multicolumn{4}{|l|}{ Residence } & \multicolumn{4}{|c|}{ Condoms break easily } \\
\hline Urban & 1.00 & 1.00 & 1.00 & Agree & 1.00 & 1.00 & 1.00 \\
\hline Periurban & $0.49(0.20-1.20)$ & $0.64(0.46-0.88)^{* *}$ & $0.64(0.45-0.92)^{*}$ & Disagree & $1.01(0.42-2.42)$ & $1.01(0.72-1.43)$ & $1.33(0.92-1.93)$ \\
\hline \multicolumn{4}{|c|}{ Yrs. of education } & \multicolumn{4}{|c|}{ ATTITUDES AND SELF-EFFICACY } \\
\hline$\leq 5$ & 1.00 & 1.00 & 1.00 & \multicolumn{4}{|c|}{ Condoms are safe } \\
\hline $6-7$ & $1.37(0.49-3.85)$ & $1.47(0.84-2.57)$ & $1.53(0.87-2.73)$ & Disagree & 1.00 & 1.00 & 1.00 \\
\hline $8-9$ & $1.75(0.59-5.17)$ & $1.51(0.88-2.58)$ & $2.80(1.60-4.90)^{* *}$ & Agree & $1.71(0.70-4.21)$ & $1.38(0.92-2.08)$ & $1.51(0.99-2.33)$ \\
\hline$\geq 10$ & $0.88(0.21-3.64)$ & $2.03(1.09-2.80)^{*}$ & $3.74(1.95-7.16)^{* *}$ & \multicolumn{4}{|c|}{ Condom use equated with lack of trust } \\
\hline \multicolumn{4}{|c|}{ Marital status } & Disagree & 1.00 & 1.00 & 1.00 \\
\hline $\begin{array}{l}\text { Single } \\
\text { Married or }\end{array}$ & \multicolumn{6}{|c|}{ Married or } & $0.65(0.44-0.95)^{*}$ \\
\hline cohabiting & na & $2.34(1.10-4.99)^{*}$ & $1.28(0.55-2.97)$ & \multicolumn{4}{|c|}{ Condoms are difficult to use with new partner } \\
\hline & & & & Disagree & 1.00 & 1.00 & 1.00 \\
\hline \multicolumn{4}{|l|}{ Employment } & Agree & $1.21(0.58-2.57)$ & $0.76(0.55-1.05)$ & $0.75(0.53-1.05)$ \\
\hline Student & 1.00 & 1.00 & 1.00 & & & & \\
\hline Employed & $0.51(0.19-1.41)$ & $0.68(0.46-1.00)$ & $0.64(0.43-0.97)^{*}$ & \multicolumn{4}{|c|}{ Condoms diminish pleasure } \\
\hline Unemployed & $0.94(0.34-2.58)$ & $0.50(0.29-0.85)^{*}$ & $0.63(0.37-1.07)$ & $\begin{array}{l}\text { Agree } \\
\text { Disagree }\end{array}$ & $\begin{array}{l}1.00 \\
0.65(0.30-1.41)\end{array}$ & $\begin{array}{l}1.00 \\
0.91(0.66-1.25)\end{array}$ & $\begin{array}{l}1.00 \\
1.16(0.83-1.62)\end{array}$ \\
\hline \multicolumn{8}{|c|}{ SEXUAL BEHAVIOR } \\
\hline \multicolumn{4}{|c|}{ Sexually active before age 15} & \multicolumn{4}{|c|}{ Embarrassed when buying condoms } \\
\hline No & 1.00 & 1.00 & 1.00 & Disagree & 1.00 & 1.00 & 1.00 \\
\hline Yes & $0.48(0.21-1.08)$ & $0.82(0.59-1.14)$ & $1.23(0.88-1.70)$ & Agree & $0.73(0.22-2.43)$ & $0.63(0.35-1.12)$ & $0.48(0.25-0.91)^{*}$ \\
\hline \multicolumn{4}{|c|}{ No. of partners in last 3 mos. } & \multirow{2}{*}{\multicolumn{4}{|c|}{$\begin{array}{l}\text { ACCESS AND AFFORDABILITY } \\
\text { Condoms are difficult to find }\end{array}$}} \\
\hline 1 & 1.00 & 1.00 & 1.00 & & & & \\
\hline \multirow[t]{2}{*}{$\geq 2$} & $0.66(0.19-2.30)$ & $0.81(0.56-1.18)$ & $1.28(0.91-1.80)$ & Agree & 1.00 & 1.00 & 1.00 \\
\hline & & & & Disagree & $4.48(1.41-14.27)^{*}$ & $1.02(0.68-1.53)$ & $1.26(0.83-1.91)$ \\
\hline \multicolumn{8}{|c|}{ KNOWLEDGE } \\
\hline \multicolumn{4}{|c|}{ Condoms prevent pregnancy } & \multicolumn{4}{|c|}{ Condoms are affordable } \\
\hline Disagree & 1.00 & 1.00 & 1.00 & Disagree & 1.00 & 1.00 & 1.00 \\
\hline \multirow[t]{2}{*}{ Agree } & $2.77(0.93-8.26)$ & $2.42(1.43-4.09)^{* *}$ & $0.94(0.57-1.55)$ & Agree & $1.35(0.57-3.18)$ & $1.41(1.00-2.01)$ & $1.71(1.19-2.46)^{* *}$ \\
\hline & & & & -2 log likelir & 221.6 & $1,016.1$ & 906.8 \\
\hline
\end{tabular}

${ }^{*} \mathrm{p}<.05 .{ }^{* *} \mathrm{p}<.01$. Note: $\mathrm{na}=$ not applicable.

anda, and thus merits further attention by program planners for both family planning and HIV-prevention programs.

One important factor related to consistent condom use among young Luandan females was equating condom use with lack of trust. This belief was associated with a significantly reduced likelihood of condom use. Furthermore, among youth in all types of relationships, lack of trust was associated with decreased odds of condom use at last intercourse. Corroborative evidence for both sexes was found in a qualitative study in Nigeria. ${ }^{29}$

Kiragu and Zabin found that high educational attainment was associated with contraceptive use, mostly condoms, among female students in Kenya. ${ }^{30}$ However, no social or demographic factors were significantly associated with contraceptive use among male students. In a study based on two Nigerian surveys, Van Rossem and colleagues reported an increase in consistent condom use with higher levels of education, especially among women. ${ }^{31}$ They also reported rates of condom use with regular or casual partners that were positively associated with higher education, concern about pregnancy or AIDS, and positive beliefs regarding condom effectiveness. Nevertheless, their results regarding the number of sexual partners and general knowledge differed from ours.

This study has a number of limitations. The KAP sample is representative of 15-24-year-olds living in Luanda, and so likely differs from this age-group in the rural population. Thus, one should be extremely cautious about generalizing these results to the rest of the country. Another limitation is that some respondents reported being in more than one type of relationship and so may be included in more than one relationship category.

As the Angolan government struggles to meet the challenges of development following decades of unrest, it must not neglect the immediate threat posed by the spread of HIV. We identified several risk factors for unprotected intercourse that education programs can address: believing that con- 
doms are not safe (for males); believing that condoms diminish pleasure (for males and females); equating condom use with lack of trust (for females and in all types of relationships); and believing that condoms do not prevent pregnancy (for those with regular partners). Although cost appears to affect condom use only in casual relationships, and accessibility affects condom use only in spousal relationships, efforts to make condoms accessible and affordable must remain at the forefront of the country's HIV-prevention campaign. Programs should also target young people's attitudes and perceptions about condoms, because an increase in condom use must play a central role if Angola is to control the spread of HIV over the next decade.

\section{REFERENCES}

1. Hatcher RA et al., Contraceptive Technology, 18th ed., New York: Ardent Media, 2004

2. Grosskurth $\mathrm{H}$ et al., Impact of improved treatment of sexuallytransmitted diseases on HIV infection in rural Tanzania-randomized controlled trial, Lancet, 1995, 346(8974):530-536.

3. Singh $\mathrm{S}$ et al., Gender differences in the timing of first intercourse: data from 14 countries, International Family Planning Perspectives, 2000, 26(1):21-28\& \& 43

4. UNAIDS/WHO Working Group on Global HIV/AIDS and STl Surveillance, Epidemiological fact sheets on HIV/AIDS and sexually transmitted infections, Angola, 2000 update (revised), <http:// www.dec.org/pdf_docs/PNACL503.pdf>, accessed Mar. 23, 2005.

5. Bongaarts J and Cohen B, Adolescent reproductive behavior in the developing world: introduction and overview, Studies in Family Planning, 1998, 29(2):99-105

6. UNAIDS/WHO, AIDS Epidemic Update: December 1998, <http:// www.unaids.org/html/pub/publications/irc-pub06/ epiupdate98_en_pdf.pdf>, accessed Feb. 15, 2002; and Rwenge M, Sexual risk behaviors among young people in Bamenda, Cameroon, International Family Planning Perspectives, 2000, 26(3):118-123 \& 130.

7. Pathfinder International, Paths into the Next Century: Adolescent Reproductive Health in Africa, Nairobi, Kenya: Pathfinder International, 1999.

8. UNAIDS, Report on the Global HIV/AIDS Epidemic 2002, Geneva: UNAIDS, 2002

9. UNAIDS/WHO, 1998, op. cit. (see reference 6).

10. Wambua LT et al., Sexual behaviour among church-going youths in Mwala Division, Kenya, East African Medical Journal, 2000, 77 (Suppl. 6):S15-S22.

11. Gage AJ, Sexual activity and contraceptive use: the components of the decision-making process, Studies in Family Planning, 1998 29(2):154-166; and Pathfinder International, 1999, op. cit. (see reference 7 ).

12. Dowsett G and Aggleton P, Sex and Youth: Contextual Factors Affecting Risk for HIV/AIDS. A Comparative Analysis of Multi-site Studies in Developing Countries, Part 1: Young People and Risk-taking in Sexual Relations, UNAIDS, 1999, <http://www.unaids.org/html/pub/ publications/irc-pub01/jc096-sex_youth_en_pdf.pdf>, accessed Apr. 25, 2002

13. Kiragu K and Zabin LS, Contraceptive use among high school students in Kenya, International Family Planning Perspectives, 1995 21(3):108-113

14. Gueye M, Castle S and Konate MK, Timing of first intercourse among Malian adolescents: implications for contraceptive use, International Family Planning Perspectives, 2001, 27(2):56-62 \& 70

15. UNAIDS/WHO, AIDS Epidemic Update: December 2001, <http //www.who.int/hiv/facts/en/isbn9291731323.pdf>, accessed Mar. 30, 2002
16. Van Rossem R, Meekers D and Akinyemi Z, Consistent condom use with different types of partners: evidence from two Nigerian surveys, AIDS Education and Prevention, 2001, 13(3):252-267.

17. Temin MJ et al., Perceptions of sexual behavior and knowledge about sexually transmitted diseases among adolescents in Benin City, Nigeria, International Family Planning Perspectives, 1999, 25(4):186190.

18. Barker GK and Rich S, Influences on adolescent sexuality in Nigeria and Kenya: findings from recent focus-group discussions, Studies in Family Planning, 1992, 23(3):199-210

19. Zlidar VM et al., New survey findings: the reproductive revolution continues, Population Reports, 2003, Series M, No. 17.

20. Agadjanian V and Prata N, War and reproduction: Angola's fertility in comparative perspective, Journal of Southern African Studies, 2001, 27(2):329-347

21. U.S. Agency for International Development, Global Health: HIV/AIDS in Angola, 2002, <http://www.usaid.gov/our_work/global_ health/aids/Countries/africa/angola_profile.pdf $>$, accessed June 27, 2002

22. UNAIDS/WHO, AIDS Epidemic Update: December 2003, <http: //www.who.int/hiv/pub/epidemiology/epi2003/en/>, accessed Dec. 15,2004

23. Centers for Disease Control and Prevention, Global AIDS Program, Angola fact sheet, 2002, <http://www.cdc.gov/nchstp/od/ gap/countries/angola.htm>, accessed June 27, 2002.

24. UNAIDS/WHO, 1998, op. cit. (see reference 6).

25. UNICEF, Inquérito de Indicadores Múltiplos (MICS), Avaliando a Situação das Crianças e das Mulheres Angolanas no Inicio do Milenio, Luanda, Angola: UNICEF and Instituto Nacional de Estatistica, 2003.

26. Ibid.

27. Singh S et al., 2000, op. cit. (see reference 3)

28. UNICEF, 2003, op. cit. (see reference 25).

29. Temin MJ et al., 1999, op. cit. (see reference 17); and UNICEF, 2003, op. cit. (see reference 25).

30. Kiragu K and Zabin LS, 1995, op. cit. (see reference 13).

31. Van Rossem R, Meekers D and Akinyemi Z, 2001, op. cit. (see reference 16)

\section{RESUMEN}

Contexto: La conducta sexual de los jóvenes de Angola jugará un importante papel en el futuro del contagio del VIH; no obstante, pocos jóvenes usan condones en forma regular y las tasas de uso de este método son bajas. Es importante identificar cuáles son los determinantes del uso del condón para los adolescentes y adultos jóvenes angoleños.

Métodos: Los datos utilizados en este análisis correspondieron a 1.995 jóvenes con experiencia sexual, de 15-24 años, que participaron en una encuesta sobre conocimientos, actitudes y prácticas realizada en 2001, en Luanda, Angola. Se realizaron análisis de regresión logística para identificar las variables de predicción del uso regular del condón entre los hombres y las mujeres, y los determinantes del uso del condón durante la última relación sexual de acuerdo con el tipo de relación de pareja.

Resultados: Tanto para los hombres como para las mujeres, el uso regular del condón estuvo positivamente relacionado con elevados niveles de educación (razones de momios, 1,7-2,6) y creer que el condón no disminuye el placer sexual $(1,8)$. Hubo una relación negativa con respecto a estar casado o cohabitar $(0,1-0,5)$. Las mujeres que consideraban que el uso del condón señalaba una falta de confianza fueron menos proclives a usar 
un condón en forma regular $(0,5)$, y los hombres que creían que el condón era un método seguro y aquellos que tenían varias parejas sexuales se mostraron más proclives a usar un condón en forma regular (1,6 y 1,7, respectivamente). La tasa de uso del condón durante la última relación sexual fue más elevada entre las parejas sexuales casuales que entre las parejas casadas (38-44\% contra 18-21\%). La residencia en un área urbana, el nivel educativo más elevado, ser estudiante y no considerar que el uso del condón indica una falta de confianza, fueron variables de predicción importantes del uso de un condón durante la última relación sexual, tanto entre las parejas regulares como entre aquellas que mantenían una relación casual; tener acceso a un condón fue el factor más importante entre las parejas casadas o que cohabitaban $(4,5)$.

Conclusiones: Los programas de intervención dirigidos a los jóvenes con menos educación, periurbanos y desempleados deben ser parte de una estrategia eficaz de prevención del contagio del VIH. Estos programas deben abordar los conceptos erróneos que tienen los jóvenes con respecto al uso del condón y la necesidad de protegerse de la infección del VIH y de otras infecciones transmitidas sexualmente.

\section{RÉSUMÉ}

Contexte: En Angola, le comportement sexuel des jeunes jouera un rôle important dans la propagation future du VIH. Peu de jeunes utilisent pourtant régulièrement le préservatif et les taux d'usage déclarés sont faibles. Il importe d’identifier les déterminants d'usage du préservatif parmi les adolescents et les jeunes adultes d'Angola.

Méthodes: Les données d'analyse proviennent de 1.995 jeunes sexuellement actifs de 15 à 24 ans ayant participé à un enquête sur les connaissances, attitudes et pratiques menée à Luanda, en Angola, en 2001. L’analyse de régression logistique a per- mis d'identifier les prédicteurs d'usage régulier du préservatif en fonction du sexe et les déterminants d'usage lors des derniers rapports en fonction du type de relation.

Résultats: Pour les jeunes hommes et femmes, l'usage régulier du préservatif s'est révélé positivement associé à de plus hauts niveaux d'instruction (rapports de probabilités 1,7-2,6) et à la croyance que la méthode ne réduit pas le plaisir sexuel $(1,8)$. Il s'est avéré négativement associé au fait d'être mariéle ou de vivre en concubinage $(0,1-0,5)$. Les jeunes femmes qui associaient l'usage du préservatif à un manque de confiance étaient moins susceptibles d'y recourir régulièrement $(0,5)$. Les jeunes hommes qui le considéraient sûr et ceux qui avaient plusieurs partenaires étaient en revanche plus susceptibles de pratiquer régulièrement la méthode (1,6 et 1,7, respectivement). Le lieu de résidence urbain, un plus hau niveau d'instruction, la scolarisation et la nonassociation du préservatif à un manque de confiance se sont avérés d'importants prédicteurs d'usage lors des derniers rapports sexuels dans les relations ordinaires ou de passage, tandis que l'accès au préservatif était le facteur le plus important dans les relations conjugales $(4,5)$.

Conclusions: Des programmes d'intervention ciblant les jeunes moins instruits, des espaces périurbains et sans emploi doivent faire partie d'une stratégie de prévention efficace du VIH. Ces programmes doivent faire face aux perceptions erronées des jeunes à l'égard de l'usage du préservatif et du besoin de protection contre le VIH et les autres IST.

\section{Acknowledgments}

The authors are grateful to Population Services InternationalAngola for generously sharing their data. We thank Andrew Noymer for his invaluable assistance.

Author contact: ndola@berkeley.edu 